\title{
Transition to legume-based farming systems requires stable outlets, learning, and peer-networking
}

\author{
Marie Mawois $^{1}$ (1) $\cdot$ Andréa Vidal $^{1} \cdot$ Eva Revoyron $^{1,2} \cdot$ Marion Casagrande $^{2,3} \cdot$ Marie-Hélène Jeuffroy $^{4}$. \\ Marianne Le Bail ${ }^{5}$
}

Accepted: 21 January 2019 / Published online: 11 February 2019

(C) INRA and Springer-Verlag France SAS, part of Springer Nature 2019

\begin{abstract}
Legume cultivation has been declining for several decades in France and in Europe as a whole. This is the result of the agri-food system lock-in around major crops, which has led to a strong simplification of cropping systems and a specialization of territories, in which legumes have been marginalized. Introducing or increasing legume production on farms has become a key issue in many European countries. Studies investigating the process of change of farmers growing legumes are missing. We analyze here the trajectories of farms cultivating legumes, with a view to understanding how and why farmers have modified their practices over the long term and to what extent this can help to support further introduction of legumes on farms. We interviewed 26 farmers growing legumes, in two French regions (Burgundy and Pays de la Loire), to understand the changes of their practices in terms of legume introduction over time. We developed a methodology to analyze farmers' trajectories based on the identification of (1) agronomic-coherence phases during which practices are stable and (2) the process of change from one coherence phase to another. The analysis of the 26 trajectories allowed us to distinguish four transitional pathways according to the speed of change, the type of legumes cultivated, and the level of legume introduction. Here, we show for the first time that the transition to a high and sustainable level of legume introduction in farms, whether progressive or as a rupture, required the combination of three levers: (1) the stability of outlets (on-farm consumption or market opportunities), (2) knowledge and local references on the preceding crop effect of legumes, and (3) the farmer's involvement in peer-networks. Our results constitute a fruitful pathway to encouraging changes for both individual and collective support for farmers to facilitate the introduction of legumes.
\end{abstract}

Keywords Changes of practices · Innovation · Diversification · Trajectory · Transitional pathways · Agricultural advisory services

\section{Introduction}

Crop diversification is often presented as an efficient means to increase the sustainability of agri-food systems (Altieri 1999;

Marie Mawois

m.mawois@groupe-esa.com

1 USC1432 LEVA, INRA, Ecole Supérieure d'Agricultures, Univ. Bretagne Loire, SFR 4207 QUASAV, 55 rue Rabelais, 49100 Angers, France

2 ISARA Lyon, Département Agroécologie et Environnement, Université de Lyon, 23 Rue Jean Baldassini, 69364 Lyon, France

3 ITAB (Institut Technique de l'Agriculture Biologique), 525 route de Gotheron, 26320 Saint Marcel les Valence, France

4 UMR Agronomie, INRA, AgroParisTech, Université Paris-Saclay, 78850 Thiverval-Grignon, France

5 UMR SAD-APT, INRA, AgroParisTech, Université Paris-Saclay, 75005 Paris, France
Médiène et al. 2011; Kremen et al. 2012; Meynard et al. 2013). Among the variety of crops that can be used, legumes (Fig. 1) afford interesting agronomic, environmental, and nutritional benefits (Voisin et al. 2014). Yet, the surface area under legume crops has been decreasing regularly in France and the rest of Europe, since the 1960s in the case of forage legumes and since the 1990s in the case of grain legumes (Schott et al. 2010; Magrini et al. 2016; Reckling et al. 2016). Several reasons explain this trend, mainly related to the increasing organization of agricultural supply chains around simplified cereal-based systems (Meynard et al. 2016) that were developed to increase food self-sufficiency after the Second World War. Due to the history of their development and to the coordination that has developed among agricultural actors, these systems benefit from more references (Zimmer et al. 2016), expertise, and adapted inputs (Vanloqueren and Baret 2009). This path dependency has progressively led the sociotechnical system to a situation of lockin and to the specialization of farms and supply chains around 


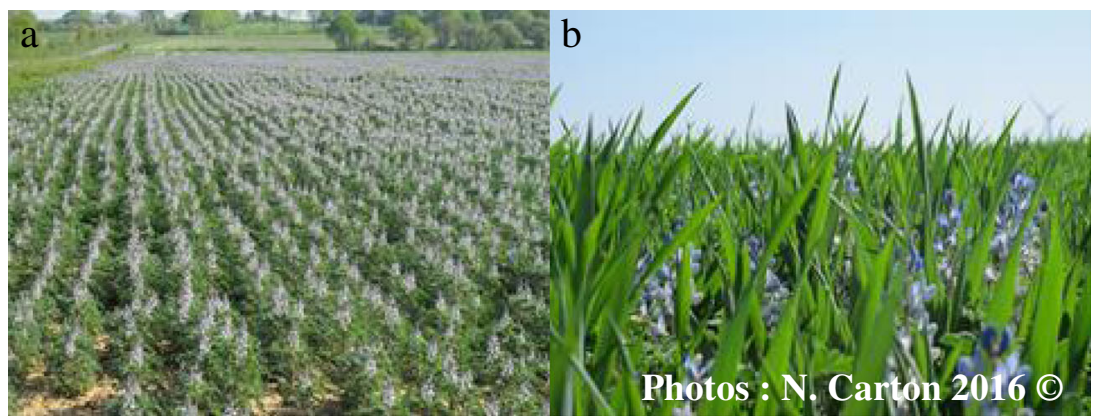

Fig. 1 In Pays de la Loire, market opportunities around Lupin supply triggered the insertion of protein crops on farms. Difficulties encountered in weed infestation for Lupin sole crop (a) can cause the farmer to discontinue it. By contrast, weed management, through Lupin-cereal intercropping for example (b), supports the maintaining of the crop but requires learning through experience and adjustments a few major crops (Magrini et al. 2016; Lamine et al. 2011; Vanloqueren and Baret 2009), thus marginalizing the others, such as legumes. Today, this constitutes an obstacle to the emergence of innovations. As a solution, theoretical studies suggest that the development of "innovation niches" may contribute to the emergence and diffusion of innovations, which could then be adopted within the dominant system (Geels and Schot 2007; Voisin et al. 2014).

Many studies have highlighted the obstacles to legume cultivation at farm and territorial level in Europe, as well as the levers that facilitate it (Meynard et al. 2013, 2016; Magrini et al. 2016; Zimmer et al. 2016; Zander et al. 2016). They provide an interesting framework to understand change at agri-food, territory, and supply-chain level; yet, they do not allow an in-depth understanding of the ongoing processes of change at farm level. This is the question that the present study aims to answer by investigating the processes of change in cropping practices over time, with a view to understanding knowledge requirements, resource management, and the decisions of those farmers who have chosen to grow legumes. The processes of change, within "niches" in which the lock-in of the dominant regime is overcome, have been studied with regard to the conversion to organic agriculture (Lamine and Bellon 2009) and the reduction of pesticide use (Chantre 2011; Chantre et al. 2015). These studies developed the notion of transitional pathways over the long term at farm level and gave us the foundations on which to build our framework. To describe processes of change towards more sustainable practices, the same authors used the ESR framework (Hill and MacRae 1995), which distinguishes three types of strategy for change: efficiency (E, optimizing the current system without a broader modification), substitution ( $\mathrm{S}$, replacing some components of the system by others), and redesign ( $\mathrm{R}$, reorganizing production systems according to ecological principles). Understanding transitional pathways requires a detailed analysis of farmers' trajectories, in order to identify the drivers of their cropping systems, their interactions with their sociotechnical and economic environment, and their learning processes (Chantre et al. 2015; Chantre and
Cardona 2014; Toffolini et al. 2016a, b). These analyses of pathways identify the mechanisms of farmers' adoption of practices, which can then be used in more general support towards change. There is a widespread agreement that analyzing innovative practices (i.e., highly different from current ones) allows us to identify levers that can be implemented on other farms and to design development scenarios for these systems (Jackson 2002; Weiner et al. 2010).

The objective of our study was therefore to analyze various individual farmers' trajectories that reflected the dynamics of long-term change in the introduction of legumes and to identify the drivers of that change (i.e., events triggering the decision to develop legumes) and the conditions in which they emerged. To this end, we developed a conceptual framework to formalize farmers' trajectories on the basis of previous research on other types of farming systems (Chantre et al. 2015; Chantre and Cardona 2014). Performing this analysis on two contrasting regions in France allowed us to identify a variety of transitional pathways for legume introduction on farms. In addition to the description of the different pathways of change concerning legumes on the surveyed farms, we analyzed the drivers of change (why and on what basis did farmers decide to develop legumes?) and the process of change itself, i.e., the procedures used to concretely implement these changes and the necessary learning process. Our results then allowed us to make propositions to support the introduction of legumes during transitional pathways on a broader spectrum of farms.

\section{Material and methods}

\subsection{Conceptual framework}

We analyzed the change in legume cultivation over time, using the concept of farmers' trajectories (Moulin et al. 2008; Chantre et al. 2015) that identifies successive "agronomic-coherence phases" separated by "transition periods."

A coherence phase corresponds to a period during which agronomic practices (in our case, those pertaining to legumes) 
as well as the decision rules behind these practices are considered to be stable, corresponding to a certain degree of legume introduction in the cropping systems.

We proposed a conceptual framework to characterize "agronomic-coherence phases" through classes. This conceptual framework (Table 1) consists of the following:

(i) a classification of crop sequences involving legumes (Table 1A) based on the agronomic literature on legumes (Nemecek et al. 2008; Carrouée et al. 2012; Voisin et al. 2014; Jeuffroy et al. 2015; Schneider et al. 2015) and on the ESR (efficiency, substitution, redesign) analysis framework proposed by Hill and MacRae (1995) and used by agro-ecology researchers (Altieri and Rosset 1996; Gliessman 2007; Lamine et al. 2011). We thus defined four types of crop sequences from short sequences with few legumes to long sequences involving several species of forage and/or grain legumes: (1) the current dominant conventional crop sequence $(C)$ in the region; (2) the "alfalfa" crop sequence (A) corresponding to the current dominant crop sequence, extended by a temporary alfalfa grassland as a starter crop; (3) a "substitution" crop sequence (S) where an annual legume crop replaces a cereal of the previous crop sequences (C or A); and (4) a "redesign" crop sequence (R) where legumes are introduced into long crop sequences with numerous crops, including intercropping, and significantly modified practices (soil tillage, fertilization, weeds, and pest control) compared with the current system.

(ii) the characterization of legume introduction on farms (Table 1B), with both the percentage of the farm UAA (utilized agricultural area) _ excluding permanent grassland areas - cultivated with legumes and the number of legume species cultivated.

(iii) the characterization of farmers' strategies, including the main objectives for integrating legumes on farms, the type of legume species cultivated, and the main use of legumes (on-farm consumption and/or sale) (Table 1C).

We thus defined nine "agronomic-coherence classes" resulting from the cross-comparison of the previous criteria (Table 1D). In class 0 , farmers do not cultivate legumes. In class 1 , the level of legume introduction is low (less than $10 \%$ and only one species). The legume grown can be a grain legume sold off the farm (class 1a) within a short crop sequence or an alfalfa crop for feeding the herd (class 1b). In class 2 (10-20\%), the level of legume introduction is higher. Legumes are cultivated either with a view to improving the farm's protein independence, along with the quality of forage for feeding the herd (class 2a), or for sale and chosen for their benefits for the following crop (class 2c) or both (class 2b). Class 3 is defined by a high level $(>20 \%)$ of legume introduction into long crop sequences, with a view to valorizing the agronomic benefits of legumes and to making the system efficient (class 3a). This agronomic benefit can be associated with the objective of protein independence for the herd (class $3 b$ ) or sale on niche markets with a high-added value (class $3 \mathrm{c}$ ).

A transition period is defined by significant changes in farmer's legume management choices, aiming a new set of goals to the agroecosystem and leading thus to another coherence phase. Each transition period involves drivers of change and process of change. The "drivers of change" correspond to the factors cited by the farmers themselves as triggering the decision to change the strategic management of legume crops (e.g., increasing the frequency of grain legume in a crop rotation). These drivers can be (i) external to the farm, related to its sociotechnical environment, such as the structuring of markets and supply chains at territorial level or changes in the regulatory context (Meynard et al. 2016); or (ii) internal to the farm and related to changes in the farmer's organizational choices or values (Navarrete and Le Bail 2007; Darnhofer et al. 2010; Mawois et al. 2012). The "process of change" corresponds to the procedures used by farmers to concretely implement the changes and the necessary learning process (how? using what resources? what learning?) from its initiation up to its adoption (or discontinuance) and ultimately its stabilization in a new coherence phase (Cerf et al. 2010; Chantre and Cardona 2014; Chantre et al. 2015).

\subsection{Data acquisition}

\subsubsection{Study area and survey sample}

The study was carried out in two French regions: the Langrois Plateau in Burgundy (B, eastern France) and the region of Chateaubriant in Pays de la Loire ( $\mathrm{P}$, western France). The two study areas have sharply contrasting soil and climates. Region B is characterized by shallow soils combined with frequent frost and drought events for crops. The yield variability is therefore greater than in zone $\mathrm{P}$, which is characterized by silty soils and a temperate climate.

The sample consisted of 13 farmers in zone P (further denoted with the letter P) and 14 farmers in zone B (further denoted with the letter B). They were drawn from a larger explorative survey of 73 farmers that aimed at identifying the agronomic and economic determinants of legume introduction (Mawois et al. 2017). In this study, our sample represents the diversity of the situations encountered in those two regions in terms of legume practices. Farms in zone $\mathrm{P}$ are oriented towards mixed farming (annual crops and dairy or beef). Maize, grain cereals, and grasslands for feeding the herd (including with hay) cover most of the farm land in these systems. In zone B, arable farms (further denoted with the letter A) and mixed farming (further denoted with the letter M) are predominant and cultivate mainly wheat, barley, and 
Table 1 Conceptual framework for establishing agronomic-coherence phases. Coherence phases (D) were obtained by cross-referencing a category of crop sequences, including legumes (A) with the degree of legume integration within the cropping system (B) associated with a strategy (C)

\begin{tabular}{|c|c|c|c|c|c|c|c|c|c|c|}
\hline $\begin{array}{l}\text { (A)Type of crop } \\
\text { sequences }\end{array}$ & \multicolumn{3}{|c|}{$\begin{array}{c}\text { Conventional " } \\
\mathrm{C} \\
\end{array}$} & \multicolumn{3}{|c|}{$\begin{array}{c}\text { "Alfalfa " } \\
\text { A }\end{array}$} & \multicolumn{2}{|c|}{$\begin{array}{c}\text { " Substitution " } \\
\text { S }\end{array}$} & \multicolumn{2}{|r|}{$\begin{array}{c}\text { Redesign " } \\
\text { R } \\
\end{array}$} \\
\hline $\begin{array}{l}\text { Description of } \\
\text { crop sequences }\end{array}$ & \multicolumn{3}{|c|}{$\begin{array}{l}\text { The current dominant conventional crop } \\
\text { sequence within the territory } \\
\text { + Introduction of legumes if they are valorized } \\
\text { well (compared to main crops) }\end{array}$} & \multicolumn{3}{|c|}{$\begin{array}{l}\text { Sequence C, extended by a temporary alfalfa } \\
\text { grassland as a strarter crop } \\
+ \text { possibly a grain legume }\end{array}$} & \multicolumn{2}{|c|}{$\begin{array}{l}\text { S1 : Sequence C, in which a protein } \\
\text { crop is integrated at the start of the } \\
\text { cropping plan, to replace a cereal } \\
\text { S2 : Sequence A, in which a cereal is } \\
\text { replaced by a protein crop }\end{array}$} & \multicolumn{2}{|c|}{$\begin{array}{l}\text { Elongation of the sequence within } \\
\text { which the legume is integrated, } \\
\text { possibly in intercropping }\end{array}$} \\
\hline $\begin{array}{l}\text { (B) Legume } \\
\text { insertion }\end{array}$ & \multicolumn{3}{|c|}{ Low level of legume insertion } & \multicolumn{3}{|c|}{ Intermediate level of legume insertion } & \multicolumn{4}{|c|}{ High level of legume insertion } \\
\hline $\begin{array}{l}\text { \% legumes in } \\
\text { crop area }\end{array}$ & \multicolumn{3}{|c|}{$0-10 \%$} & \multicolumn{3}{|c|}{$10-20 \%$} & \multicolumn{4}{|c|}{$=$ or $>20$ (up to $50 \%)$} \\
\hline $\begin{array}{l}\text { Number of } \\
\text { legumes species }\end{array}$ & \multicolumn{3}{|c|}{$0-1$ species } & \multicolumn{3}{|c|}{2 species } & \multicolumn{4}{|c|}{$2-5$ species } \\
\hline (C) Strategies & \multicolumn{3}{|c|}{ Opportunistic way } & \multicolumn{3}{|c|}{ Improving the economic independence } & \multicolumn{4}{|c|}{ Valorize pre-crop services (agronomic and economic) } \\
\hline Objectives & $\begin{array}{l}\text { Conventional } \\
\text { crops }\end{array}$ & $\begin{array}{c}\text { One-time } \\
\text { diversification } \\
\text { crops }\end{array}$ & Feed & $\begin{array}{l}\text { Self-sufficient } \\
\text { in forage } \\
\text { legumes }\end{array}$ & $\begin{array}{l}\text { Improve protein } \\
\text { independence } \\
\text { and diversify } \\
\text { cropping systems }\end{array}$ & $\begin{array}{c}\text { Economic } \\
\text { benefit at crop } \\
\text { sequences level }\end{array}$ & $\begin{array}{l}\text { Valorize the agronomic } \\
\text { services of legumes }\end{array}$ & $\begin{array}{l}\text { Food self-su } \\
\text { the herd and } \\
\text { agronomi }\end{array}$ & $\begin{array}{l}\text { fficiency for } \\
\text { valorize the } \\
\text { services }\end{array}$ & $\begin{array}{c}\text { Positioning on niche } \\
\text { markets with a high } \\
\text { added value and valorize } \\
\text { the agronomic services }\end{array}$ \\
\hline $\begin{array}{l}\text { Legumes } \\
\text { cultivated }\end{array}$ & No legumes & Grain legumes & Alfalfa & \begin{tabular}{|c|}
$\begin{array}{c}\text { Alfalfa with or } \\
\text { without other } \\
\text { forage }\end{array}$ \\
\end{tabular} & \multicolumn{2}{|c|}{ Alfalfa and protein crops } & $\begin{array}{l}\text { Protein crops and/or } \\
\text { forage crops }\end{array}$ & \multicolumn{3}{|c|}{ Protein crops and forage crops } \\
\hline $\begin{array}{l}\text { Main use of } \\
\text { legumes }\end{array}$ & & Sale & $\begin{array}{c}\text { On-farm } \\
\text { consumption }\end{array}$ & $\begin{array}{c}\text { On-farm } \\
\text { consumption }\end{array}$ & $\begin{array}{c}\text { On-farm } \\
\text { consumption and } \\
\text { sale } \\
\end{array}$ & Sale & $\begin{array}{l}\text { On-farm consumption } \\
\text { and sale }\end{array}$ & On-farm cc & nsumption & Sale \\
\hline $\begin{array}{l}\text { (D) Coherence } \\
\text { classes }\end{array}$ & $\mathbf{0}$ & 1a & 1b & $2 \mathrm{a}$ & $2 b$ & $2 \mathrm{c}$ & 3a & & b & $3 \mathrm{c}$ \\
\hline
\end{tabular}

rapeseed. The sample is composed both of mixed farms (20) and arable farms (6) in conventional (19) or organic (7) farming (organic farms are further denoted with “*”).

Alfalfa, intended for on-farm consumption, is the main legume grown on the mixed farms in both study areas. It is also grown on arable farms of zone B, where farmers deliver it to a cooperative that dehydrates it and sells it mainly to local livestock farmers. Other protein crops are also cultivated for the feed stuff markets (e.g., peas) and processed by local cooperatives with appropriate infrastructure (sorting and storage). In zone $\mathrm{P}$, a lupin supply chain for human consumption is managed by a cooperative.

\subsubsection{Interviews with farmers}

In-depth surveys were carried out in 2016 in the form of two series of semi-structured interviews on each farm. The first series of interviews were aimed at understanding the individual farmers' trajectories and focused on the following: (i) the current cropping systems and practices of the farm, to understand the general characteristics as well as decision-making rules of the cropping system and the technical management of legumes, and (ii) the evolution of the farm and its management since 1990, with a focus on the changes in cropping systems and practices concerning legumes. A first analysis of these data enabled us to roughly outline farmers' trajectories, showing the dynamics of change for legume introduction over the time. The second series of interviews more specifically addressed the processes of change on the farm with respect to legumes and included two steps: (i) validation and improvement, with the farmer, of the trajectory built from the first interview and (ii) analysis of changes in practices for legume introduction, specifying the nature of the change, the drivers of change, and the learning processes.

\subsection{Data analysis}

All the interviews were recorded and transcribed into a database describing for each farm:

i) an overview of the farming system in 2016 (labor; equipment; plots and soil types; livestock; main inputs and outputs of the system) with a detailed description of the cropping systems' and legume crops' management rules and principles

ii) the nature and date of the main changes that occurred in the strategic management of legumes between 1990 and 2016, corresponding to changes in one coherence phase of the farming system to another with regard to legumes

iii) for each transition period from one coherence phase to another, information cited by the farmers on the elements that triggered the changes (drivers of change) and the procedures used by farmers to concretely implement these changes (process of change), including the experimentation and learning processes involved

\subsubsection{Building the farmer's trajectories}

Based on the conceptual framework and the data gathered from the interviews, we framed the individual trajectories of 
change of the 26 farms. First, we characterized the current (in 2016) coherence phase of the farms (based on the classes described in Table 1D). Second, we traced the successive agronomic-coherence phases since 1990 for each farm. Finally, we identified the drivers of change cited by the farmers and the processes of change involved for each transition period during farms' trajectories. Based on the analysis of the overall sample of farms, we distinguished different types of drivers and processes in order to highlight those that had a significant effect on the maintenance of or increase in the level of legumes.

\subsubsection{Identifying transitional pathways}

We built a typology of transitional pathways by grouping together trajectories that were similar (Chantre et al. 2015) in terms of the sequence of phases and the intensity of the change regarding legumes. Drawing on the literature on transitions (Lamine and Bellon 2009; Petit and Aubry 2015), we defined the intensity of the change by the following: (i) the speed of the change, corresponding to the number and duration of agronomic-coherence phases covering the 1990-2016 period, and (ii) the difference between the original system and the current one, corresponding to the nature of the change between two successive coherence phases. For example, a pathway can be described both as (i) progressive or abrupt change dynamics and (ii) the predominance of minor changes (progression between coherence phases within the same class, Table 1C) or major changes (progression between coherence phases pertaining to different classes).

\section{Results and discussion}

\subsection{Current agronomic-coherence phases of legume introduction on farms}

First, we characterized the current agronomic-coherence phases of the 26 farms (Fig. 2). The fact that no farmer interviewed is in class 0 is consistent with the aim of our study. Five farms, mainly located in zone B, are in class 1a. They cultivate grain legumes (peas or lupin) in an opportunistic way, if there is nothing more profitable to produce. The three farms in class $1 \mathrm{~b}$ are mixed farmers in zone $\mathrm{P}$ who use alfalfa for feeding the herd. For those farms (in classes $1 \mathrm{a}$ and $1 \mathrm{~b}$ ), the area under legumes is less than $10 \%$ of the UAA, and the number of species is low. Six farms are currently in class 2 and have an area between 10 and $20 \%$ of the UAA under legumes. Farms in zone B benefit from the services of a dehydration factory, which enables them to valorize a greater area of alfalfa (classes $2 \mathrm{a}$ and $2 \mathrm{c}$ ). In zone $\mathrm{P}$, the only mixed farmer in phase $2 \mathrm{a}$ aims at being self-sufficient in forage legumes by cultivating an intercrop of triticale, vetch, and grain peas in addition to alfalfa, as the mixed intercrop is easier to store. The other farmers from zone $\mathrm{P}$ in class $2 \mathrm{~b}$ are livestock farmers who aimed at achieving feed-independence for their herd and benefitting from the effect of diversification of their arable area. Classes $3 \mathrm{a}, 3 \mathrm{~b}$, and $3 \mathrm{c}$ are represented by two different types of farm with different objectives: (a) organic farms (mainly in zone B), which consider legumes both as a protein-rich product for feeding animals and as a source of nitrogen and which grow legumes in intercrops for better control of pest populations; and (b) conventional mixed farms in zone $\mathrm{P}$, which use the preceding crop effect on soil structure improvement to move towards a reduced or no tillage system, with the area under legumes ranging between 20 and $50 \%$ of the UAA, including various legume species.

Our analysis of current agronomic-coherence phases highlights a wide diversity of current situations concerning legume introduction on farms, in which farms cover all three classes of agronomic-coherence phases in both regions. Moreover, legumes are introduced both on mixed farms and on arable farms and both in organic farming (predominant in the third class) and in conventional farming. Thus, despite many obstacles to legume introduction on farms (Meynard et al. 2013; Voisin et al. 2014; Magrini et al. 2016), our study shows that they are still cultivated in all types of farming system (mixed or arable farms; organic or conventional systems) and both regions.

\subsection{Pathways of change on farms with respect to legume introduction}

The frame of the 26 individual trajectories of change (Fig. 3) allowed us to identify different coherence phases that farmers passed through to introduce, increase, and/or stabilize (or not) legumes in their cropping systems. We highlighted a diversity of pathways in terms of the following: (i) the number and the classes of "agronomic-coherence phases" experienced by farmers over time; (ii) the duration of the phases; and (iii) the gaps between two successive phases (from continuous change to more radical change). The transition from a conventional crop sequence (phase 0 or 1 ) to a high level of legume introduction (phase 3: more than $20 \%$ of the UAA) occurred in six farms from our sample. It takes from 2 to 7 years, with a mean of 5 years. We identified four main types of pathways with regard to the introduction of legumes.

\subsubsection{Pathway A}

"Instability" corresponds to five farms, which cultivate between 0 and 2 protein crops in an area representing less than $10 \%$ of the UAA throughout the trajectory without challenging the dominant crop sequence. These five farms were in phase 1a in 2016. They produced legumes opportunistically, and the level of legume introduction and the types of legumes 
cultivated were instable over time. Since 1990, three farms changed coherence phase from class 0 to class 1 a. Two farms gave up alfalfa at the beginning of the pathway, changing from phase $2 \mathrm{a}$ or $2 \mathrm{~b}$ during the 1990 s to phase 1a today. The changes undergone during the 2010 s resulted from a substitution of oilseed crops and cereals by grain legumes, in reaction to technical obstacles mainly related to the control of harmful pest populations on these species that predominate in terms of sequences and landscapes. These changes were strengthened by an increase in European subsidies allocated to protein crops (PM1, BA1, PM8). In such pathways, the level of legume introduction remained low, and farmers could replace them at any time by other more attractive crops.

\subsubsection{Pathway B}

"Stability" is a characteristic of mixed farms (except for farmer BA7, who stopped his livestock farming but continued to produce alfalfa to sell to other livestock farmers with whom he had worked in the past). This "stability" pathway B was organized around alfalfa. Depending on the region, the change resulted in either the introduction or the increase of alfalfa. In zone P, farmers had not cultivated alfalfa in the 1990s. The change from phase 0 to phase $1 \mathrm{~b}$ occurred around 2007 in response to a strategic choice with a view to improving protein self-sufficiency in a context of increasing soy prices. Up to now, these farms have maintained this alfalfa-based crop sequence, thus staying within class 2 (Table 1). For farms in zone B that have been cultivating alfalfa since 1990, the change from one phase to another (between $2 \mathrm{a}, 2 \mathrm{~b}$, and $2 \mathrm{c}$ ) was characterized by an increase of their forage legume areas or by the introduction of a grain legume in their crop sequences. In such pathways, the proportion of legume crops on farms remained stable (between 5 and $20 \%$ of the UAA), which directly linked with the amount of legumes required for feeding the herd and/or with the storage and sell capacities.

\subsubsection{Pathway C}

"Continuous increase" covers seven farms that progressively increased legume cultivation within crop sequences, going through three coherence phases in average within the pathway. The initial agronomic-coherence phases, which differed between zone B (phase 2b) and zone $\mathrm{P}$ (phase 0 ), determine the current level of legume introduction (higher degree of introduction in B). These farms progressively changed their crop sequences from "classic" (in zone P) or "alfalfa" (in zone B) to "substitution" or, even more broadly, resulting in "redesign" crop sequences. In zone $\mathrm{P}$, the first legume introduced was alfalfa (and possibly grain legumes) in a proportion lower than $10 \%$ of the UAA, changing from phase 0 to phase $1 \mathrm{a}$ or 1b. Later, farmers gave legumes a strategic place within the cropping system, thus reaching "substitution" or "redesign" crop sequences (phase 3 ) with adapted crop management (for example, reduction in nitrogen fertilization on the crops planted after legumes and simplified seeding techniques). In zone $B$, the transition from phase $2 b$ to phase 3 resulted from a conversion to organic agriculture.
Fig. 2 Distribution of the current agronomic-phases of the 26 farms. $B=$ farms located in zone B (Burgundy, eastern France) and $\mathrm{P}=$ farms located in zone $\mathrm{P}$ (Pays de la Loire, western France); $M=$ mixed farms; $\mathrm{A}=$ arable farms; $*$ = organic farms

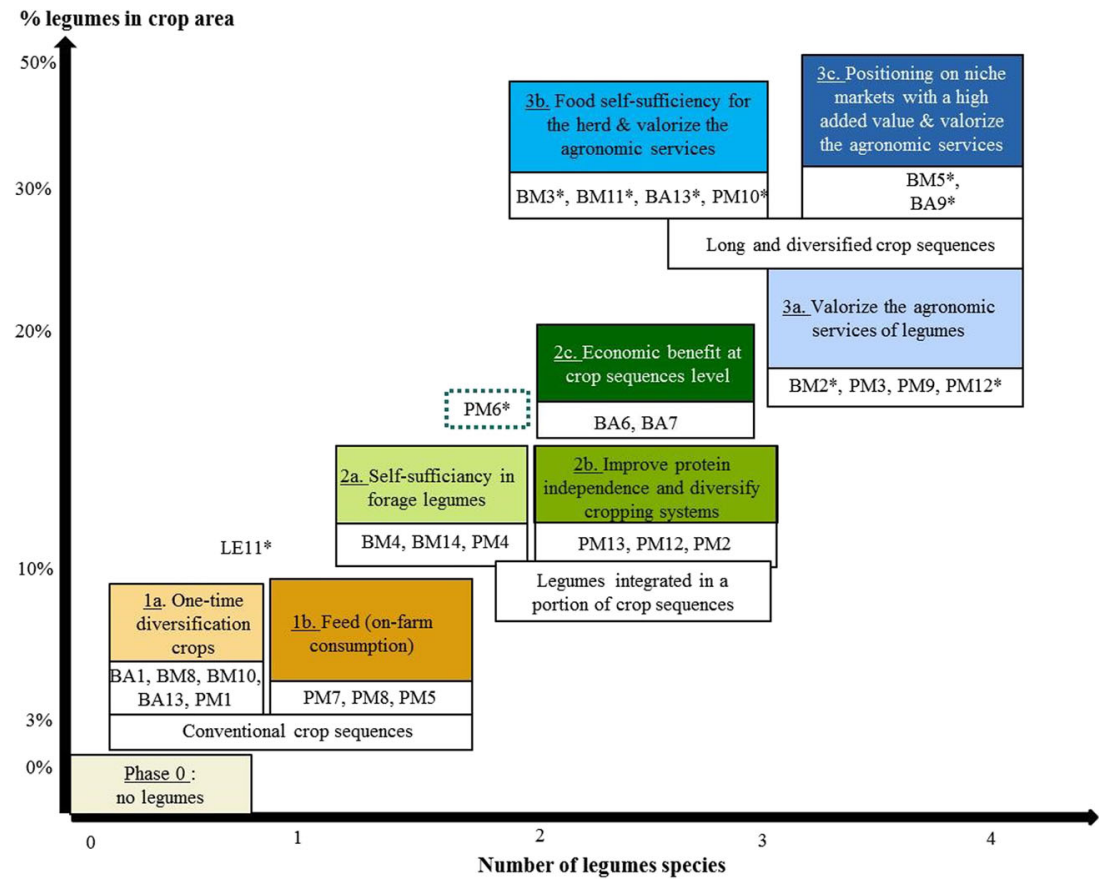




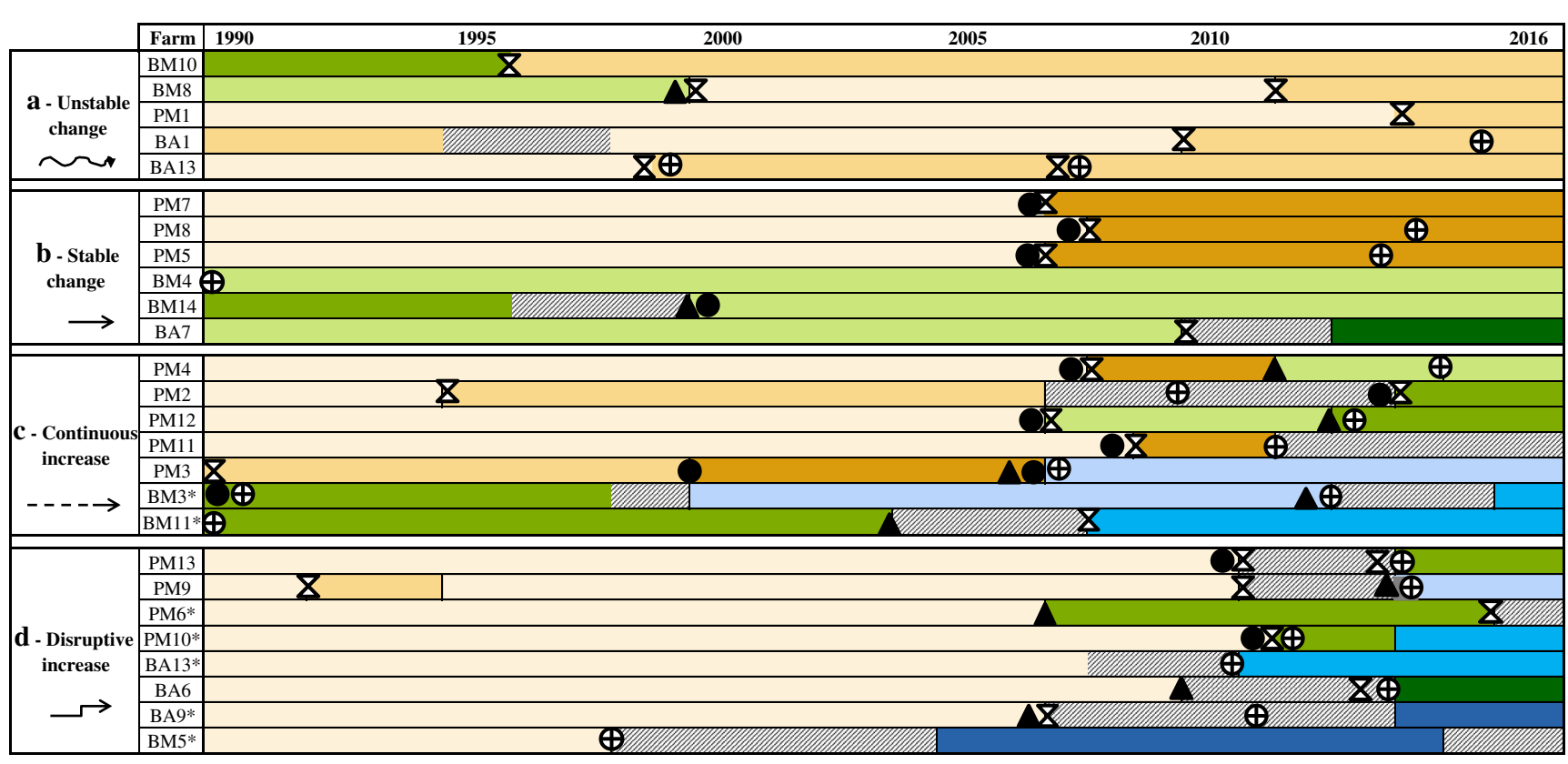

Fig. 3 Transitional pathways in farms with respect to legumes insertion. $\mathrm{B}=$ farms located in zone $\mathrm{B} ; \mathrm{P}=$ farms located in zone $\mathrm{P} ; \mathrm{M}=$ mixed farms; $\mathrm{A}=$ arable farms; $*$ = organic farms. The trajectories of change of the 26 farms are characterized by successive agronomic-coherence phases: $\square$ class $0 ; \square$ class $1 \mathrm{a} ; \square$ class $1 \mathrm{~b} ; \square$ class $2 \mathrm{a} ; \square$ class $2 \mathrm{~b}$; $\square$ class 2c; $\square$ class 3a; $\square$ class 3b; $\square$ class 3c and

\subsubsection{Pathway D}

"Disruptive increase" concerns the trajectories with the most radical changes, spanning multiple coherence phases within a rather limited period. These changes resulted in a radical revision of farmers' strategy in terms of cropping plan and crop sequences. Transition phases were long (3 to 7 years): farmers empirically tested the changes (new crops or practices) prior to stabilizing their system with a high level of legumes. The transition was fairly smooth for two farms from phase 0 (no legumes) to phase $2 \mathrm{a} / 2 \mathrm{~b}$ (intermediate level of legume introduction), but more radical for five farms from phase 0 to phase $3 \mathrm{a} / 3 \mathrm{~b} / 3 \mathrm{c}$ (high level of legume introduction) with the implementation of a "substitution" or "redesign" crop sequence.

Despite the general decrease in the surface area under legumes both in France and in the rest of Europe (Voisin et al. 2014; Magrini et al. 2016; Zander et al. 2016), we show transitional pathways towards more legumes in farms. As other studies have already noted (Lamine and Bellon 2009; Chantre 2011; Chantre et al. 2015), changes were implemented stepby-step. This progressiveness of transition pathways may produce robustness, as seen in the conversion towards organic farming (Lamine 2011). If the sustainable introduction of legumes is to be supported, it is crucial that we consider the progressiveness of the change process. Moreover, depending on the farms, the dynamic of change concerning legume crops differs in terms of (i) the speed of the change, (ii) the type of legumes cultivated, and (iii) the level of legume introduction. periods. The transition from one coherence phase to another is triggered by one or multiple drivers of change: $\boldsymbol{Z}$ economic and regulatory context; - outlet (livestock management or market opportunities); $\oplus$ valorization of pre-crop benefits; $\boldsymbol{\Delta}$ change in available resources (areas, labor, livestock farming, materials)

This diversity of situations leads to individual adaptation of legume introduction, rather than the massive generic option designed for a wide range of farms and agricultural conditions (Prost et al. 2016).

Agronomists have recently proposed the concept of "stepby-step design" (Meynard et al. 2012) to underline the processes leading from the current situation to the desired one (Chantre and Cardona 2014). That type of method produces very particular and local design solutions (Prost et al. 2016). Nevertheless, once the new system has been designed (after several feedback loops), the way to support farmers in introducing such systems on their farms is rarely addressed. Our analysis of the various types of pathways and agronomiccoherence phases could therefore be useful for agronomists and farmers to design "intermediate cropping systems" together. The idea is not to identify in which trajectory the farmer is, but to be able to support farmers to make choices and redesign their system by discussing the various ways they could take. Hence, supporting farmers in the introduction of more legumes on farms does not require one to be an expert on legumes, but rather to be able to identify the dynamics of change and to support farmers' ability to change (Dulcire 1997; Toffolini et al. 2016b).

\subsection{Drivers of change with respect to legumes}

The transition from phase 0 to phase 1 a (introduction of legumes on a one-time basis) was frequently associated with 
external drivers of change (Fig. 3) related to the economic and regulatory context (price of crops and subsidies) (Table 2, quotes 1 and 2). When the sale price of the legume crop combined with European subsidies due to common agricultural policies (CAP) was more attractive than that of the major crops, the farmer decided to sow this crop (thus reasoning mainly on an annual scale). However, when this driver occurred alone, the introduction of legumes could very quickly be compromised by a change in the context (Table 2, quote 3). Such situations often occurred in pathway A, in which economic and regulatory contexts were the main drivers of change. Within this "instability" pathway A, the benefit of the crop was only evaluated at crop level (gross margin of the crop). When considering grain legumes in crop choice, farmers are often faced with their low economic value according to standard assessments conducted at crop level, i.e., low gross margins and high production risks compared with competing crops (Preissel et al. 2015). In such an approach (i.e., comparing margins and risks at crop level), the contribution of legumes crops to subsequent crops in the cropping systems (pre-crop benefits) is underestimated by the farmers. The scale of the crop sequence is a better basis for the assessment of legume competitiveness (Schneider et al. 2010; Preissel et al. 2015; Reckling et al. 2016; Zander et al. 2016). Moreover, the instability of prices and subsidies, along with the varying severity of pest populations' impact on yields, increases uncertainty on crop gross margins (Meynard et al. 2013) in a context of a lack of information and advisory support on these crops (Zimmer et al. 2016). Even though the economic and regulatory context often triggers the introduction of legume crops on farms, this driver alone appears as insufficient to maintain the new crop. To achieve more widescale and sustainable legume introduction in farms over time, farmers often cited the role played by other drivers.

A change in farmers' objectives with regard to livestock management (wish to be self-sufficient and/or to improve the herd's health) resulted in forage legume increases on farms (alfalfa or sainfoin on certain organic farms in zone B). This change was often stable (10 to $20 \%$ of the UAA, corresponding to the area required to cover at least a portion of the herd's needs). The livestock managements' driver often occurred in pathway B, "stability." According to the surveyed farmers, alfalfa was often cited as a quality forage source, primarily for its protein content and also for its positive impact on herd health (limiting acidosis, favoring rumination, etc.) (Table 2, quote 4$)$. These changes were sometimes facilitated by external factors related to the socioeconomic context: the soybean price increase resulted in the decision to reduce nitrogen supplements (Table 2, quote 5) or the development of market opportunities within the territory, as shown in other studies (Magrini et al. 2016). In zone B, the collecting areas of the dehydrated alfalfa factory increased steadily (from 800 ha in 1996 to 1500 ha in 2015), thus allowing farmers to increase their alfalfa crop area (Table 2, quotes 6 and 7). The presence of the dehydration factory was a lever to mitigate the difficulties of storing alfalfa hay and afforded flexibility to livestock farmers, who could either sell their surplus or purchase it after dehydration for the deferred consumption by their herd. In addition, the factory could take care of the harvesting, thus removing one of the main technical and organizational obstacles related to this crop. For the same reasons, the absence of alfalfa processing solutions in zone $\mathrm{P}$, which would permit both long-term storage and a reduction in the workload (harvest and post-harvest work done by the factory), is an obstacle to the development of this crop (Table 2, quote 8). In zone P, market opportunities around Lupin supply triggered the introduction of protein crops on farms, but the collecting area was limited by the cooperative's selling capacities. Finally, these drivers (the decision to change livestock management and/or the market opportunities within the territory) triggered the introduction or increase of legume crops in farms. Yet, the room for maneuver at farm level to increase the surface area under legume crops remains narrow. The proportion of legume crops on farms is limited by the herd's requirements (the quantity of consumed legumes proteins), the available land to grow legumes on, and/or the storage and selling capacities of the cooperatives (Huyghe and Delaby 2013; Schneider et al. 2015; Mawois et al. 2017).

The consideration of the economic and agronomic benefits of legumes evaluated on a multiyear basis led to systems in which legumes were even more present (in terms of $\%$ of the UAA, number of species, and introduction within crop sequences). These benefits were determined on a rotationbased approach and met multiple objectives, which are consistent with the literature on legume crops (Table 2, quotes 9 to 13): (i) to reduce nitrogen supply for the following crop (Cernay etal.2016); (ii) to improveyield of the following crop (Bennett et al. 2012; Schneider et al. 2015); (iii) to break weed cycles (Deytieux et al. 2012; Bennett et al. 2012); and (iv) to improve soil structure (Nemecek et al. 2008, Kopke and Nemecek 2010). Furthermore, we found that the more the pre-crop benefits of legumes were taken into account in the management of the cropping system, the higher the level of legume introduction was (case of farms in pathway D). Our results are thus consistent with those of Toffolini et al. (2016a, b) who highlighted the fact that farmers mostly use knowledge on pre-crop benefits when they are redesigning their systems. Farms with more than $20 \%$ legumes often consider a combination of these effects to justify the choice to introduce legumes. Taking into account the pre-crop benefits of legumes led to the implementation of "substitution" or "redesign" sequences with an adaptation in the technicalmanagementofthe following crop (reduction of inputs, soil tillage, etc.). Contrary to situations in pathway A (pre-crop benefit evaluated at crop level), the pre-crop benefit of legumes was greater when considered in a rotation-based approach (Preissel et al. 
Table 2 Examples of quotes for drivers and process of change

(a) Drivers of change with respect to legumes

1 I choose my pea cropping plan solely based on the price of rapeseed. So long as I can continue to grow rapeseed, I will (BA1)

2 What motivates us to cultivate peas is the $C A P^{(1)}$. Today, they pay a couple hundred euros more when you cultivate peas [...] we are already valorizing them a bit on the level of sales, and it's true that the fact of getting a CAP subsidy motivates us (BA13*)

3 It's going to be profitable because we'll have a protein subsidy, so we are going to get an $A E M^{(2)}$. [...] Next year, they are announcing a decrease of $€ 100$ per ton for soybean, so that does not really make us want to embark on cultivating those crops (BA1)

4 If alfalfa is cultivated on farm, it's mainly because of its positive effect on rumination as well as its calcium and protein content (PM11)

5 I save 21,000 euros a year on nitrogen supplements (PM6*)

$6 \quad$ Nearby, there's a factory, so we can grow it. Otherwise it would not work (BA7)

We take 80 tons and then leave the rest to the factory and it sells it. That pays for a portion of the dehydration cost (BM14)

8 If there was a dehydration factory near my farm, I would not hesitate to increase the area of alfalfa grown. But without one, constraints in terms of labor force organization, and the quality of the final product are too important (PM8)

9 The wheat that comes afterwards is really good wheat. We can reduce the nitrogen supply, so it's beneficial (BA6)

$10[\ldots]$ we are not going to have to add nitrogen, because the peas and lupins will be there to provide nitrogen to the following cereal (PM10*)

11 After faba beans, we get 15 more quintals compared with wheat following maize (PM13)

12 The beneficial effect is enormous in terms of weed control ... it really cleans the field (BA13*)

13 Initially, legumes revitalize the life of the soil (PM9)

14 Lupin is planted in September, wheat in October, and afterwards, in November, it will be faba beans. It's because I am trying to divide up my time ... (PM9)

15 I am taking fewer risks by changing than by remaining in this situation! (PM13) D

(b) Process of change with respect to legumes

16 The constraint was the harvest. The yield was already very small, and we did not always A manage to harvest under the best conditions (BM10)

17 [...] The wheat afterwards is dirty because the pea crop lets numerous weeds. I tried to grow alone peas, lentils, faba beans, but, after all these years of experience, I banned myself from growing these crops alone; they are always in intercropping (BM5*)

18 Weed infestation is binding for lupin. Lupin-triticale intercropping hinders weed infestation (PM10*)

19 For them, protein crops are too specific and there is no technical advisory today (PM2) C

20 That is the way it is in these big institutes, there is a certain slowness (BM5*)

21 We cropped soya for the first time, it is not a common crop in the region. Nobody, even our advisory services, could really help us (BM14)

22 I like to observe things for myself, but that takes time (BM14)

$23[. .$.$] we share many information and experiences within the GEDAR. The first year when I$ cultivated peas, I was very involved in the exchanges, it helped me (BA6)

24 I wanted to make experiments, and I had read in magazines that intercrops were possible. As weed infestation in alfalfa is very binding, I tried (PM3)

25 The BASE network allows me to benefit from the experience of others, whether good or bad, and therefore to establish new references. On top of that, I have to carry out my own experiments to confirm what I hear about the agronomic benefits of legumes and to understand the processes to be able to act on them (PM3)

26 I have contacted some institutes' advisors; some bases were interesting but insufficient. Then, it is more through trainings and networking with other organic farmers ... (BA13*)

(1) Common agricultural policy; (2) (agri-environmental measure)

2015; Reckling et al. 2016; Zander et al. 2016) and supports the stable introduction of legumes (pathways $\mathrm{C}$ and D).

Changes valorizing legumes could be triggered by drivers of change related to the available resources at farm level (mainly surface areas and labor force). They could be related to a change in the structure of the farm itself (increase in available resources). For instance, increasing the surface area of the farm allowed the farmer to grow legumes without 
reducing the areas of other crops (PM2, BM3*); when livestock farming activities were stopped, labor and land were freed up (PM9, PM12); when a new farmer settled on the farm, this could change the strategic objectives and provide new opportunities (PM6*; BA6; BA13*; PM7).

Changes could also be related to farmers wishing to change the strategic direction of the farm in order to change their workload as a way of life. For example, this is the case of farmers who integrated legumes to stagger the workload (Table 2, quote 14). Such situations often occurred in pathways $\mathrm{C}$ and $\mathrm{D}$, in which we note that the limited available resources at farm level (PM6*: limited UAA; BA6 and PM9: limited workforce) could facilitate change in favor of legumes.

These drivers of change highlighted in our study (economic and regulatory context; management of herds' feed; economic and agronomic benefits; available resources) are consistent with those in other studies (Meynard et al. 2013; Magrini et al. 2016; Mawois et al. 2017). Our results however allow a better understanding of how these drivers occur. We see that they did not all occur in the different pathways and not at the same time. We found that certain changes were triggered only in the presence of certain drivers of change. The economic and regulatory context was often the main driver occurring at the beginning of the change. But, as we have shown, it was not sufficient to lead to stable introduction of legumes on farms when it occurred alone (case of pathway A). Most often, change was triggered by a combination of drivers. The transition to a high level of legume introduction (pathways $\mathrm{C}$ and $\mathrm{D}$ ) was often triggered by the combination of agronomic considerations, with driving factors external to the farm (market opportunities within the territory, economic and regulatory context, etc.).

The pathway with the most significant rupture (pathway D) was encountered by farmers having lower risk aversion to change (Table 2, quote 15). Some farmers believed that the risks of technical errors in the conversion to organic agriculture were largely offset by their conviction that it was the only way of reaching a profitable system (PM6*, PM11*, PM10*). Behind the drivers previously cited, step-by-step changes in pathways $\mathrm{B}$ and $\mathrm{C}$ were also often a response to the progressive emergence of organizational, environmental, and ethical concerns internal to the farm (increased independence for the herd or for crop inputs, observations of environmental impacts, desire for independence with respect to technical structures). These results converge with those of other studies (Darnhofer et al. 2010; Nave et al. 2013), showing that farmers' strategic choices are determined largely by their personality, preferences, and competences and are reinforced by the opportunities offered by their external environment.

The drivers of change highlighted here induce willingness to change and make the introduction or development of legumes on the farm possible. The way in which farmers actually tested this change, either effectively implementing it or rejecting it, is related to the process of change, i.e., the procedures to concretely execute these changes (How did farmers execute the changes? What learning process was necessary?).

\subsection{Processes of change with respect to legumes on farms}

During the process of change, behavioral postures when faced with difficulties encountered in the technical management of the crop have a major influence on the changes implemented. The management of weed infestation, the control of pest populations, and harvest management emerge as key practices for the success of these crops - with differences, depending of the crop (weed infestation and harvest appear as key issues for alfalfa). A significant decline in legume yields or failures related to technical difficulties reinforced by the lack of local references often led to (i) the discontinuance of the crop (Table 2, quote 16) or (ii) mechanisms of "substitution" of legume species by other crops. By contrast (farms in pathways $\mathrm{C}$ and $\mathrm{D}$ ), when the farmer encountered technical difficulties, he favored legume introduction (Table 2, quotes 17 and 18). When the technical management is controlled, legumes are more likely to be maintained, although this requires learning through experience and adjustments (trial and error) in practices on the crop sequence level: in pathway $\mathrm{C}$, adjustments took place in a step-by-step way with several phases during the trajectory; in pathway $\mathrm{D}$, the change was more disruptive, with only two phases during the trajectory but with a long transition period with many technical adjustments. These adjustments led to the implementation of a crop sequence consistent with the introduction of the legume ("redesign"). The resolution of these technical difficulties reduced yield uncertainty and therefore the economic valorization of the crop and subsequent crops. It generally resulted in the stabilization of the crop, quickly or more slowly, depending on the farmer and the resources mobilized during the change process. The comparison of successful or disrupted individual experiences may become a means to produce an "appropriate action" reference (Cerf et al. 2010) in the implementation of a technical lever. Focusing on the learning process during phases of experimentation may thus highlight key practices and evaluation indicators to be shared across territories.

To benefit from support in the implementation of and follow-up to the technical management of a legume, all farmers in the sample called upon the technical advisors of the Chamber of Agriculture or the cooperative. However, the significance of this support for learning varied widely and was inadequate for many farmers (Table 2, quotes 19 to 21), as Zimmer et al. (2016) have also shown. Farmers in pathway A mainly made use of classic information resources (journals, websites, advisers) to introduce the change, mainly on a few 
plots, to limit risks. Farmers in pathway B mainly based themselves on observations in the field, in order to manage technical adjustments progressively (PM7, PM5, BM14), thus justifying processes of minor change over the long term (Table 2, quote 22). A few of them (PM8, BA7, BM4) completed these observations through their involvement in farmer networks or by following local tests. On farms in pathway $\mathrm{C}$, we observed a transformation in the learning methods used in the management of changes over the course of their pathway. In fact, the first resources mobilized by farmers were similar to those in pathways A and B (classic information resources and observations in the fields). Later, considering the pre-crop effect of legume resulted in a need to mobilize other resources to manage benefits on the following crops. Farmers in pathways $\mathrm{C}$ and $\mathrm{D}$ therefore combined two types of resource: (i) involvement in exchange networks within the territory (for example: PM4, PM3, LO9, PM2: network on conservation tillageBASE - in zone P; BA1, BA7, BM3*: network for agricultural development-GDA-in zone B) (Table 2, quote 23) and (ii) reference to experiments that are carried out either by themselves on the farm (PM3, BM3, PM11*, BA9*, BM5*, BA6*: Table 2, quote 24) or by their neighbors or local development entities (PM6*, PM9, PM10*, PM2, PM4, BM11). The farmers that display the highest levels of legume introduction (pathways $\mathrm{C}$ and $\mathrm{D}$ ) combined both individual and group forms of experiences to compensate for a lack of local technical resources and to ensure that agronomic innovation is properly adapted to their specific use, both for forage legumes and for grain legumes (Table 2, quotes 25 and 26).

Here, we show the importance of networks for robust transitions towards the increased introduction of legumes: the more farmers are involved in networks and in building local references and knowledge, the more they cultivate legumes sustainably. Our results agreed with those of studies on the effects of collective dynamics and networks on learning and technical change (Darré 1994; Norton et al. 1999; Warner 2007; Schneider et al. 2009; Girard 2015). During the process of change, the new knowledge and know-how that were applied contributed primarily to reducing the farmer's aversion to risk (Lamine et al. 2011).

Our results are consistent with Chantre et al. (2015) and Chantre and Cardona (2014) who clearly demonstrated, in the context of innovative practices for the reduced application of pesticides, that the farmers who adopted the most sophisticated reasoning in this regard diversified their "learning styles" over time, during the course of their pathway of change, and combined individual and collective forms of experience. In our sample, the involvement of farmers within group networks is clearly associated with an increase in the introduction of legumes. Meynard et al. (2018) maintain that these networks animate dynamics of collective change through learning based on peers' experience. On the other hand, contrary to the findings of studies on the reduction in pesticide use (Chantre 2011; Chantre et al. 2015), the technical trials carried out by neighbors or members of the network are enough for many farmers in our sample to assess the best way to integrate legumes within their system, without needing to carry out trials on their own farm prior to adopting the crop. One can assume that, for many farmers, introducing a legume seems to be less risky than decreasing their use of pesticides.

These results call into question the prescriptive methods of advisers (Cerf et al. 2010) used for individual support and show the importance of the availability of technical references on the territorial scale, regarding crop sequences rather than the crops themselves (Meynard et al. 2013, 2016). In the literature, the role of peer groups has long been highlighted in innovation processes in agriculture (Darré 1985). The group dynamic is identified as an important factor in the construction of professional identity and as a factor of reassurance during periods of transition and departure from a "dominant" professional identity when levels of uncertainty are high (Goulet et al. 2008; Lamine et al. 2011). In addition to being a source of innovation, local networks encourage the development of a narrative of experiences on which farmers can draw in order to better pinpoint problems in their specific situation and to identify possible solutions (Cerf et al. 2010). In this sense, our findings are consistent with the study by Meynard et al. (2013) who highlight the fact that supporting farmers through the strengthening of experiments and advisory networks, as well as sharing innovative experiences within farmer groups, appears to be crucial in ensuring the endurance of these crops on the farms and within the areas in which they are introduced. As advisers are not the only source of information for farmers, helping farmers to combine a variety of learning sources could be a way to support change on farms. Such approaches require innovative pedagogical approaches, such as farmer to farmer methods, which are often highlighted as a key factor in agroecological expansion (Altieri et al., 2012). It could enable to compare, in addition to their results, their respective intentions and reasons for implementing a given innovation and applying their own evaluation indicators, which are generally not the same ones that agronomists have established (Toffolini et al. 2016). This comparison may be an opportunity to improve on-station and on-farm trials by more systematically bringing together farmers in terms of the way of wording the problem of constructing ad hoc evaluation indicators, etc. Moreover, the knowledge intensity of agroecological practices (Tomich et al. 2010; Altieri and Nicholls 2012; De Schutter 2010), such as the introduction of legumes, requires complementary research to fill in the gap between generic scientific knowledge and local knowledge with a view to locally adapting agricultural innovations (Caron et al. 2014; Duru et al. 2015). In this way, researchers recently developed new participative approaches for helping farmers in designing innovative systems (Lefèvre et al. 2014). In this work, farmers were involved in the prototyping process to design cropping 
systems tailored to the local conditions of the participant farms. However, as Casagrande et al. (2015) have shown, when looking for capitalization and operationalizing existing knowledge and experiments, even though such a participatory approach is relevant, the designed prototypes might lack creativity. To overcome the lack of creativity and support, farmers introduce more changes. Prost et al. (2016) suggest drawing on recent design theories, such as $\mathrm{C}-\mathrm{K}$ theory (Hatchuel et al. 2013; Ezzat et al. 2017), which focus on the mechanisms that allow an exploration of a part of the unknown to favor creativity.

Finally, because legumes are not dominant in the study regions, networks are critical for accessing knowledge and references. Even though the economic and regulatory context often triggers the introduction of legume crops on farms, it appears as insufficient to maintain the new crop over time. Technical difficulties often occurred and can lead to the discontinuation of the crop. The involvement in peer-networks appears here as a response to the lack of knowledge and reference, a finding which is consistent with the growing body of farmer-to-farmer extension work (Holt-Giménez 2010; Guerra et al. 2017). These studies showed that regulatory context can provide an economic incentive to begin an agroecological transition by creating a price-differentiated market, but it is limited in stimulating a broader scaling up of agroecological production without external network linkages. These findings can be useful to question the way in which public policy (such as CAP) could foster robust transitions towards agroecological practices on a wide scale.

\section{Conclusion and perspectives}

Change with respect to legume introduction on farms is progressive. The transition from a conventional crop sequence to a high level of legume introduction takes from 2 to 7 years into our sample. It occurs through several successive agronomiccoherence phases or, more radically, through long transition phases. The analysis of pathways of change in practices related to legume introduction on farms allowed us to highlight a variety of drivers and processes of change. If a farmer's strategy is purely economic and/or if there are limited market opportunities (internal to the farm in the case of on-farm consumption by the herd or external), he or she will not consider legumes to be a stable long-term option. However, if his or her needs increase, supported by a more stable external market opportunity (example of the dehydration factory in zone B or the lupin supply chain in $\mathrm{P}$ ) and by the acknowledgement of the pre-crop benefits of legumes for the entire crop sequence, these crops will be present to a greater degree and will also be integrated better into crop sequences. In this case, the process of change towards the increased introduction of legumes, whether progressive or as a rupture, requires learning through experience via involvement in peer exchange networks. In these networks, experiences are combined in order to solve the technical difficulties encountered and to address a lack of local references for crop management.

The stage at which a farmer is on his or her pathway of change and the relationship between innovative practices and learning methods, involving a greater or lesser degree of interaction between individual and collective experiences, must all be taken into consideration to adapt support for change to a farmer's situation. We believe that these different elements constitute fruitful pathways to encourage changes in the support for farmers on an individual and collective level in order to facilitate the increased introduction of legumes.

Acknowledgments The authors thank the farmers from Burgundy and Pays de la Loire who took part in the survey for giving their time.

Funding information This study was done with the financial support from the ANR Legitimes-AGOBIOSPHERE program (ANR-13AGRO-0004).

\section{Compliance with ethical standards}

Conflict of interest The authors declare that they have no conflict of interest.

Publisher's note Springer Nature remains neutral with regard to jurisdictional claims in published maps and institutional affiliations.

\section{References}

Altieri M (1999) The ecological role of biodiversity in agroecosystems. Agric Ecosyst Environ 74(1-3):19-31. https://doi.org/10.1016/ S0167-8809(99)00028-6

Altieri M, Nicholls CI (2012) Agroecology scaling up for food sovereignty and resiliency. In: Lichtfouse, E. (Ed.), Sustain. Agric. Rev., vol. 11. Springer, Netherlands, pp. 1e29. Doi: https://doi.org/10.1007/ 978-94-007-5449-2 1

Altieri M, Rosset P (1996) Agroecology and the conversion of large-scale conventional systems to sustainable management. Int J Environ Stud 50:165-185. https://doi.org/10.1080/00207239608711055

Altieri M, Funes-Monzote F, Petersen P (2012) Agroecologically efficient agricultural systems for smallholder farmers: contributions to food sovereignty. Agron Sustain Dev 32(1):1-13. https://doi.org/10. 1007/s13593-011-0065-6

Bennett AJ, Bending GD, Chandler D, Hilton S, Mills P (2012) Meeting the demand for crop production: the challenge of yield decline in crops grown in short rotations. Biol Rev 87:52-71. https://doi.org/ 10.1111/j.1469-185X.2011.00184.x

Caron P, Biénabe E, Hainzelin E (2014) Making transition towards ecological intensification of agriculture a reality: the gaps in and the role of scientific knowledge. Curr Opin Environ Sustain 8:44-52

Carrouée B, Schneider A, Flénet F, Jeuffroy MH, Nemecek T (2012) Introduction du pois protéagineux dans des rotations à base de céréales à paille et colza: impacts sur les performances économiques et environnementales. Innov Agron 25:125-142

Casagrande M, Lefèvre V, Capitaine M, Peigné J (2015) Participative design of conservation agriculture cropping system in organic agriculture. 5th International Symposium for Farming Systems Design 
(AGRO2015) In: Proceedings of the 5th International Symposium for farming systems design "Multi-functional farming systems in a changing world". 2015. $553 \mathrm{p}$

Cerf M, Omon B, Chantre E, Guillot MN, Le Bail M, Lamine C, Olry P (2010) Vers des systèmes économes en intrants : quelles trajectoires et quel accompagnement pour les producteurs en grandes cultures? Innov Agron 8:105-119

Cernay C, Pelzer E, Makowski D (2016) A global experimental dataset for assessing grain legume production. Dryad Digital Repository 3: 160084. https://doi.org/10.1038/sdata.2016.84

Chantre E (2011) Farmers' learning processes in implementing low-input field crop agriculture: case study of Champagne Berrichonne (Indre, France) during the years 1985-2010. Thesis (PhD), AgroParisTech, Paris Institute for Life, Food and Environmental Sciences, 397pp

Chantre E, Cardona A (2014) Trajectories of French field crop farmers moving toward sustainable farming practices: change, learning, and links with the advisory services. Agroec Sustain Food Syst 38(5): 573-602. https://doi.org/10.1080/21683565.2013.876483

Chantre E, Cerf M, Le Bail M (2015) Transitional pathways towards input reduction on French field crop farms. Int J Agric Sustain 13(1):69-86. https://doi.org/10.1080/14735903.2014.945316

Darnhofer I, Bellon S, Dedieu B, Milestad R (2010) Adaptiveness to enhance the sustainability of farming systems. A review. Agron Sustain Dev 30(3):545-555. https://doi.org/10.1051/agro/2009053

Darré JP (1985) Les dialogues entre agriculteurs : Etude comparative dans deux villages français, Bretagne et Lauragais. Langues et Sociétés 33(1):43-64 http://www.persee.fr/doc/lsoc_0181-4095 1985 num $33 \quad 1203$

Darré JP (1994) Pairs et experts dans l'agriculture. Dialogues et production de connaissance pour l'action. Erès, Paris

De Schutter O (2010) Report submitted by the special rapporteur on the right to food to the Human Rights Council at the Sixteenth Session of the UN General Assembly, 20 December 2010. United Nations, New York

Deytieux V, Nemecek T, Knuchel RF, Gaillard G, Munier-Jolain NM (2012) Is integrated weed management efficient for reducing environmental impacts of cropping systems? A case study based on life cycle assessment. Eur J Agron 36:55-65. https://doi.org/10.1016/j. eja.2011.08.004

Dulcire M, (1997) A partnership to achieve an impact : what kind of agronomic research can contribute to the evolution of agricultural practices. Workshop "Linking Participatory Methodologies with People's Reality", Brighton, UK

Duru M, Therond O, Fares M (2015) Designing agroecological transitions; a review. Agron Sustain Dev 35(4):1237-1257. https://doi. org/10.1007/s13593-015-0318-x

Ezzat H, Le Masson P, Weil B (2017) Leading in the unknown with imperfect knowledge: situational creative leadership strategies for ideation management. 24th Innovation and Product Development Management (IPDM) Reykjavik, Iceland

Geels FW, Schot J (2007) Typology of sociotechnical transition pathways. Res Policy 36(3):399-417. https://doi.org/10.1016/j.respol. 2007.01.003

Girard N (2015) Knowledge at the boundary between science and society: a review of the use of farmers' knowledge in agricultural development. J Knowl Manag 19(5):949-967. https://doi.org/10.1108/ JKM-02-2015-0049

Gliessman SR (2007) The ecology of sustainable food systems, second ed. In: Agroecology CRC Press. CRC Press. 2nd Ed. $384 \mathrm{p}$

Goulet F, Pervanchon F, Conteau C, Cerf M (2008) Les agriculteurs innovent par eux-mêmes pour leurs systèmes de culture, In Reau $\mathrm{R}$ and Doré $\mathrm{T}$ (éd.). Systèmes de culture innovants et durables: quelles méthodes pour les mettre au point et les évaluer?. Dijon, Educagri Editions, p. 53-69

Guerra, J., Blesh, J., Schmitt Filho, A.L., Wittman, H., 2013. Pathways to agroecological management through mediated markets in Santa
Catarina, Brazil. Elem Sci Anth 5(0):67:1-16. https://doi.org/10. 1525/journal.elementa.248

Hatchuel A, Weil B, Le Masson P (2013) Towards an ontology of design: lessons from $\mathrm{C}-\mathrm{K}$ design theory and forcing. Res Eng Des 24:147163. https://doi.org/10.1007/s00163-016-0233-4

Hill SB, MacRae RJ (1995) Conceptual frameworks for the transition from conventional to sustainable agriculture. J Sustain Agric 7(1): 81-87. https://doi.org/10.1300/J064v07n01_07

Holt-Giménez E (2010) Grassroots voices: linking farmers' movements for advocacy and practice. J Peasant Stud 37:203-236

Huyghe C, Delaby L (2013) Prairies et systèmes fourragers: pâturage, ensilage, foin. Agriproduction (2e ed.). Paris, FRA: Editions France Agricole. http://prodinra.inra.fr/record/282253

Jackson W (2002) Natural systems agriculture: a truly radical alternative. Agric Ecosyst Environ 88:111-117. https://doi.org/10.1016/S01678809(01)00247-X

Jeuffroy MH, Biarnès V, Cohan JP, Corre-Hellou G, Gastal F, Jouffret P, Juste E, Landé N, Louarn G, Plantureux S, Schneider A, Thibeau P, Morison M, Vertes F (2015) Performances agronomiques et gestion des légumineuses dans les systèmes de productions végétales. Les légumineuses pour des systèmes agricoles et alimentaires durables, Editions Quae, 512 p., 2015, 978-2-7592-2334-3

Kopke U, Nemecek T (2010) Ecological services of faba bean. Field Crop Res 115:217-233. https://doi.org/10.1016/j.fcr.2009.10.012

Kremen C, Iles A, Bacon C (2012) Diversified farming systems: an agroecological, systems-based alternative to modern industrial agriculture. Ecol Soc 17(4):44. https://doi.org/10.5751/ES-05103-170444

Lamine C (2011) Transition pathways towards a robust ecologization of agriculture and the need for system redesign. Cases from organic farming and IPM. J Rural Stud 27(2):209-219. https://doi.org/10. 1016/j.jrurstud.2011.02.001

Lamine C, Bellon S (2009) Conversion to organic farming: a multidimensional research object at the crossroads of agricultural and social sciences. A review. Agron Sustain Dev 29(1):97-112. https://doi. org/10.1051/agro/2008007

Lefèvre V, Capitaine M, Peigné J, Roger-Estrade J (2014a) Farmers and agronomists design new biological agricultural practices for organic cropping systems in France. Agron Sustain Dev 34(3):623-632. https://doi.org/10.1007/s13593-013-0177-2

Magrini MB, Anton M, Cholez C, Corre-Hellou G, Duc G, Jeuffroy MH, Meynard JM, Pelzer E, Voisin AS, Walrand S (2016) Why are grainlegumes rarely present in cropping systems despite their environmental and nutritional benefits? Analyzing lock-in in the French agrifood system. Ecol Econ 126:152-162. https://doi.org/10.1016/ j.ecolecon.2016.03.024

Mawois M, Aubry C, Navarrete M, Le Bail M (2012) Modelling spatial extension of vegetable land use in urban farms. Agron Sustain Dev 32(4):911-924. https://doi.org/10.1007/s13593-012-0093-x

Mawois M, N'Guyen G, Casagrande M (2017) Freins et leviers à l'insertion des légumineuses : étude comparative de trois territoires contrastés (Bourgogne, Midi-Pyrénées, Pays de la Loire). Innovations agronomiques. Innov Agron 60:91-105

Médiène S, Valantin-Morison M, Sarthou JP, de Tourdonnet S, Gosme M, Bertrand M, Roger-Estrade J, Aubertot JN, Rusch A, Motisi N, Pelosi C, Doré T (2011) Agroecosystem management and biotic interactions: a review. Agron Sustain Dev 31(3):491-514. https:// doi.org/10.1007/s13593-011-0009-1

Meynard JM, Dedieu B, Bos AP (2012) Re-design and co-design of farming systems. An overview of methods and practices. In: Darnhofer I, Gibbon D, Dedieu B (eds) Farming systems research into the 21st century: the new dynamic. Springer Netherlands, Dordrecht, pp 405-429

Meynard JM., Messean A, Charlier M, Charrier F, Fares M, Le Bail M, Magrini MB (2013) Freins et leviers à la diversification des cultures : étude au niveau des exploitations agricoles et des filières. OCL 20(4). doi : https://doi.org/10.1051/ocl/2013007 
Meynard JM, Jeuffroy MH, Le Bail M, Lefèvre A, Magrini MB, Michon C (2016) Designing coupled innovations for the sustainability transition of agrifood systems. Agric Syst 157:330-339. https://doi.org/ 10.1016/j.agsy.2016.08.002

Meynard JM, Charrier F, Le Bail M, Magrini MB, Charlier A, Messéan A (2018) Socio-technical lock-in hinders crop diversification in France. Agron Sustain Dev 38(5):54. https://doi.org/10.1007/ s13593-018-0535-1

Moulin $\mathrm{CH}$, Ingrand S, Lasseur J, Madelrieux S, Napoleone M, Pluvinage J, Thénard V (2008) Comprendre et analyser les changements d'organisation et de conduite de l'élevage dans un ensemble d'exploitations: propositions méthodologiques. In: Dedieu et al. (ed), L'élevage en mouvement. Flexibilité et adaptation des exploitations d'herbivores, Update Sciences and Technologies, Editions Quae

Navarrete M, Le Bail M (2007) SALADPLAN: a model of the decisionmaking process in lettuce and endive cropping. Agron Sustain Dev 27(3):209-221. https://doi.org/10.1051/agro:2007009

Nave S, Jacquet F, Jeuffroy MH (2013) Why wheat farmers could reduce chemical inputs: evidence from social, economic, and agronomic analysis. Agron Sustain Dev 33(4):795-807. https://doi.org/10. 1007/s13593-013-0144-y

Nemecek T, Von Richthofen JS, Dubois G, Casta P, Charles R, Pahl H (2008) Environmental impacts of introducing grain legumes into European crop rotations. Eur J Agron 28:380-393. https://doi.org/ 10.1016/j.eja.2007.11.004

Norton GW, Rajotte EG, Gapud V (1999) Participatory research in integrated pest-management: lessons from the IPM. Agric Hum Values 16:431-439. https://doi.org/10.1023/A:1007608019218

Petit C, Aubry C (2015) Typology of organic management styles in a cash-crop region using a multicriteria method. Org Agric 6:155. https://doi.org/10.1007/s13165-015-0124-4

Preissel S, Reckling M, Schläfke N, Zander P (2015) Magnitude and farm-economic value of grain legume pre-crop benefits in Europe: a review. Field Crop Res 175:64-79. https://doi.org/10.1016/j.fcr. 2015.01.012

Prost L, Berthet E, Cerf M, Jeuffroy MH, Labatut J, Meynard JM (2016) Innovative design for agriculture in the move towards sustainability: scientific challenges. Res Eng Des 28:119-129. https://doi.org/10. 1007/s00163-016-0233-4

Reckling M, Hecker JM, Bergkvist G, Watson CA, Zander P, Schläfke N, Stoddard FL, Eory V, Topp F, Maire J, Bachinger J (2016) A cropping system assessment framework - evaluating effects of introducing legumes into crop rotations. Eur J Agron 76:186-197. https://doi.org/10.1016/j.eja.2015.11.005

Schneider F, Fry P, Lederman T, Rist S (2009) Social learning processes in Swiss soil protection - the 'from farmer-to farmer'project. Hum Ecol 37(4):475-489. https://doi.org/10.1007/s10745-009-9262-1
Schneider A, Flénet F, Dumans P, Bonnin E, De Chezelles E, Jeuffroy MH, Hayer F, Nemecek T, Carrouée B (2010) Diversifier les rotations céréalières notamment avec du pois et du colza-Données récentes d'expérimentations et d'études. OCL 17:301-311. https:// doi.org/10.1051/ocl.2010.0332

Schneider A, Huyghe C, Maleplate T, Labalette F, Peyronnet C, Carrouée B (2015) Rôle des légumineuses dans l'agriculture française. In Les légumineuses pour des systèmes agricoles et alimentaires durables. Quae

Schott C, Mignolet C, Meynard JM (2010) Les oléoprotéagineux dans les systèmes de culture : évolution des assolements et des successions culturales depuis les années 1970 dans le bassin de la Seine. OCL 17:1-16. https://doi.org/10.1051/ocl.2010.0334

Toffolini Q, Jeuffroy MH, Prost L (2016a) Indicators used by farmers to design agricultural systems: a survey. Agron Sustain Dev 36(1):114. https://doi.org/10.1007/s13593-015-0340-z

Toffolini Q, Jeuffroy MH, Prost L (2016b). L'activité de re-conception d'un système de culture par l'agriculteur: implications pour la production de connaissances en agronomie. Agriculture, Environnement et Société, Association Française d'Agronomie 6(2)

Tomich TP, Brodt S, Ferris H, Galt R, Horwath WR, Kebreab E, Leveau JHJ, Liptzin D, Lubell M, Merel P, Michelmore R, Rosenstock T, Scow K, Six J, Williams N, Yang L (2010) Agroecology: a review from a global-change. Annu Rev Environ Resour 36:193-222. https://doi.org/10.1146/annurev-environ-012110-121302

Vanloqueren G, Baret P (2009) How agricultural research systems shape a technological regime that develops genetic engineering but locks out agroecological innovations. Res Policy 38(6):971-983. https://doi. org/10.1016/j.respol.2009.02.008

Voisin AS, Guéguen J, Huyghe C, Jeuffroy MH, Magrini MB, Meynard JM, Pelzer E (2014) Legumes for feed, food, biomaterials and bioenergy in Europe: a review. Agron Sustain Dev 34:361-380. https://doi.org/10.1007/s13593-013-0189-y

Warner KD (2007) Agroecology in action: extending alternative agriculture through social networks. The MIT Press, London

Weiner J, Andersen SB, Wille WKM, Griepentrog HW, Olsen JM (2010) Evolutionary agroecology: the potential for cooperative, high density, weed-suppressing cereals. Evol Appl 3(5-6):473-479. https:// doi.org/10.1111/j.1752-4571.2010.00144.x

Zander P, Amjath-Babu T, Preissel S, Reckling M, Bues A, Schläfke N, Kuhlman T, Bachinger J, Uthes S, Stoddard F, Murphy-Bokern D, Watson C (2016) Grain legume decline and potential recovery in European agriculture: a review. Agron Sustain Dev 36(2):1-20. https://doi.org/10.1007/s13593-016-0365-y

Zimmer S, Liebe U, Didier JP, Heß J (2016) Luxembourgish farmers' lack of information about grain legume cultivation. Agron Sustain Dev 36(1):1-10. https://doi.org/10.1007/s13593-015-0339-5 